\title{
Implementasi Penegakan Hukum Tindak Pidana Aborsi Dikalangan Remaja Kota Ternate
}

\author{
Nolfan Hibata1, Gunawan Hi Abas ${ }^{2}$ \\ 1,2Fakultas Ilmu Sosial dan Ilmu Kependidikan, Program Studi Hukum, Universitas Hein Namotemo \\ E-mail: nolfanhibata91@gmail.com
}

\begin{tabular}{l} 
Article Info \\
\hline Article Histo \\
Received: 2021-1 \\
Revised: 2021-11 \\
Published: 202 \\
\\
Keywords: \\
Criminal Law; \\
Abortion; \\
Teenager; \\
Ternate.
\end{tabular}

Sejarah Artikel

Diterima: 2021-11-02

Direvisi: 2021-11-22

Dipublikasi: 2021-12-04

\section{Kata kunci:}

Hukum Pidana;

Aborsi;

Remaja;

Ternate.

\begin{abstract}
This research is a qualitative research with a descriptive method, the results of the study show that the factors behind teenagers in the city of Ternate committing the crime of abortion are because there are several problems in their minds and psychology, namely there are economic factors that make them sometimes think personally they are still difficult to have an income. especially by feeding babies. social factors, sometimes they think that this globalization condition is a lot to live freely in the end they can go along with relatives who have done this. the factor is still in college or school, this factor sometimes makes them feel afraid of being found out by their family, friends in the village, even afraid of everything they do so that their psychology is not ready to get married. and the personal impact experienced, even the lack of responsibility for adolescents increases the tendency for adolescents to have abortions. In various regions, every year many women, especially teenagers, experience unwanted pregnancies. Most of these teenagers choose to terminate their pregnancy even though they know it is against the law and prohibited by religion. Abortion is interesting to discuss because although it is prohibited by law, the number tends to increase from year to year.
\end{abstract}

\section{PENDAHULUAN}

Kota Ternate bukan saja menjadi kota transip perdagangan dari seluruh pulau halmahera, tapi juga menjadi salah satu kota untuk pendidikan kususnya di Maluku Utarkan, kini sebagian besar adik-adik dari berbagai daerah halmahera, menuntut pendidikannya dikota ternate, dengan berbagai kampus/universitas dikota ternate yang hadir kini menambah usaha para pengusaha rumah kontrakan dan rumah kos-kosan bertambah banyak bagian ternate utara dan ternate selatan, tetapi yang menjadi salah satu problem para pengusaha rumah kos-kosan ini tidak terlalu mempunyai sistem aturan yang dimilikinya tidak terlalu ketat, hingga sering terjadi ada kos-kosan yang asal terima saja penghuni, apakah dari perempuan maupun lelaki yang digabung dalam satu mes kos-kosan, hampir sebagian besar rumah kos-kosan di Ternate ini, penghuninya digabung satu mes yaitu laki-laki dan perempuan, hal seperti inilah membuka peluang besar terjadi kumpol kebo dikos-kosan sering terdapat dikota ternate, 
untuk itu seharusnya ini juga membutuhkan kontrol serius pada pemerintah kota ternate, apakah membuat salah satu Perda untuk regulasi pengelola rumah kos-kosan, ataukah membangun sebuat kontrol sosial yang kuat dimasingmasing kelurahan, bisah dipisahkan kamar koskosan wanita dan kmar kos-kosan laki-laki, untuk menjaga kemungkinan ada kumpul kebo para mahasiswa atau masyarakat yang hidup dalam asrama kos-kosan.

Prasangkanya kalau nanti ada kumpulkumpul itu sangat tidak baik. Bukan hanya agama yang dilarang, tapi sering terjadi kehamilan di luar nikah, bahkan sampai ada perbuatan melawan hukum yaitu aborsi ilegal. Ini biasanya terjadi di kalangan pelajar. melakukan ini karena mereka takut ketahuan, keluarga tahu. Di desa, dan mereka mengira masih kuliah, jangan sampai orang tua mereka tahu bahwa mereka akhirnya melakukan tindakan yang tidak mencerminkan nilai-nilai agama dan sosial tersebut, aborsi adalah topik hangat selamanya, dan telah menjadi topik diskusi di semua lapisan masyarakat, banyak tempat, negara, forum resmi dan forum informal lainnya. Sebenarnya masalah ini sudah terjadi berkali-kali sejak zaman dahulu. -Kota besar dan daerah terpencil. Aborsi merupakan masalah kesehatan masyarakat karena memberikan dampak pada kesakitan dan kematian ibu. Sebagaimana diketahui penyebab utama kematian ibu hamil dan melahirkan adalah perdarahan ,infeksi dan eklampsia. Hal itu terjadi karena hingga saat ini aborsi masih merupakan masalah kontroversial di masyarakat. Di satu pihak aborsi dianggap ilegal dan dilarang oleh agama sehingga masyarakat cenderung menyembunyikan kejadian aborsi, di lain pihak aborsi terjadi di masyarakat. Ini terbukti dari berita yang ditulis di surat kabar tentang terjadinya aborsi di masyarakat.

A. Definisi Aborsi

Keguguran adalah berakhirnya kehamilan (karena akibat tertentu) sebelum buah kehamilan dapat bertahan hidup di luar rahim/kehamilan yang tidak diinginkan atau diinginkan. Aborsi sendiri terbagi menjadi dua jenis, yaitu aborsi spontan dan aborsi buatan. Aborsi spontan adalah aborsi spontan tanpa upaya eksternal (buatan) untuk mengakhiri kehamilan. Aborsi buatan adalah keguguran yang terjadi karena suatu usaha untuk mengakhiri proses kehamilan. Keguguran adalah keluarnya produk kehamilan secara prematur dari embrio uterus atau janin yang tidak dapat hidup (Dorland, 2002). Dengan kata lain, keguguran adalah kematian janin karena penghentian kehamilan sebelum usia kehamilan 20 minggu.

Ada dua jenis aborsi, yaitu aborsi spontan, aborsi spontan tanpa intervensi medis (aborsi spontan), dan aborsi terencana (aborsi induksi) melalui pengobatan, pembedahan, atau prosedur medis lain yang menyebabkan pendarahan vagina. (Fauzi, dkk., 2002), Pengertian keguguran adalah berakhirnya kehamilan sebelum janin (fetus) mencapai usia 20 minggu setelah sel telur (ovum) yang telah dibuahi berimplantasi di dalam rahim (uterus). Keguguran atau keguguran (bahasa Latin: abortus) adalah pengguguran janin; aborsi dianggap sebagai pengguguran kandungan (disengaja karena tidak menginginkan bayi yang belum lahir). Biasanya dilakukan saat janin masih muda (sebelum bulan keempat kehamilan), Faktor penyebab dari kejadian aborsi ini antara lain adalah:

1. Faktor Sekolah dan Kuliah

Dimana kebanyakan anak sekolah maupun mahasiswa diternate hidupnya do asrama kosan, jarang terkontrol oleh pihak keluarga, ini yang membuat mereka hidup dengan bebas melakukan apapun, hingga sampai terjadi kompul kebo dikamar kosan, sampai terjadi kehamilan diluar nikah, dengan berbagai macam pertimbangan, masih sekolah dan kuliah ahirnya mereka ketakutan diketahui oleh keluarga dan orang tua, jalan satu-satunya mereka berani untuk melakukan tindak pidana aborsi.

2. Faktor Hamil diluar nikah

Diera sekarang hidup bebas ini banyak terjadi faktor hamil diluar nikah, ini yang mempunyai pengaruh psikologi yang sangat besar besar untuk pasangan muda mudi yang berani melakukan apa saja demi menggugurkan kandungan yang dikandung oleh seorang pacar, karena karena malu diketahui teman,orang kampung bahkan keluarga ahirnya mereka bisah melakukan tindakan aborsi.

3. Faktor ekonomi

Dimana dari pihak pasangan suami isteri yang sudah tidak mau menambah anak lagi karena kesulitan biaya hidup, namun tidak memasang kontrasepsi, atau dapat juga karena kontrasepsi yang gagal, ahirnya mereka berpikir jalan satu-satunya melakukan perbuatan melawan hukum tersebut. 
4. Faktor lainnya

Seperti para pekerja seks komersial, 'perempuan simpanan', pasangan yang belum menikah dengan kehidupan seks bebas atau pasangan yang salah satu/ keduanya sudah bersuami/ beristri (perselingkuhan) yang terlanjur hamil, aborsi menurut konstruksi yuridis Peraturan Perundang-Undangan di Indonesia adalah tindakan mengugurkan atau mematikan kandungan yang dilakukan dengan sengaja oleh seorang wanita atau orang yang disuruh melakukan untuk itu. Wanita hamil dalam hal ini adalah wanita yang hamil atas kehendaknya ingin mengugurkan kandungannya, sedangkan tindakan yang menurut KUHP dapat disuruh untuk lakukan itu adalah tabib, bidan atau juru obat. Pengguguran kandungan atau pembunuhan janin yang ada di dalam kandungan dapat dilakukan dengan berbagai macam cara, misalnya: dengan obat-obatan yang diminum, berbagai macam cara obat yang dibeli untuk bisah menggugurkan kandungan.

Maraknya praktek Aborsi pada saat ini seakan menjadi fenomena sosial yang sulit terpecahkan. Dari tahun ke tahun jumlah orang yang melakukan praktek Aborsi semakin bertambah dan tentunya ini menjadi cerminan untuk semua pihak agar dapat mencari solusi yang terbaik di dalam penyelesaian kasus aborsi tersebut. Kurangnya kesadaran masyarakat dan remaja, dalam memahami dampak dari tindakan aborsi tersebut bagi kesehatan dan nyawa, serta ancaman hukum bagi pelaku aborsi tersebut, kurangnya pengawasan orang tua dalam mengawasi anak, tidak adanya laporan dari pihak rumah sakit bagi pasien yang telah melakukan tindakan pasca aborsi criminal, diharapkan agar kepolisian dapat meningkatkan profisional penyidik dalam menangani maupun mengungkap kasus tindak pidana aborsi di Kota Ternate, serta penyidik kepolisian tidak hanya sekedar menunggu laporan, namun dapat melakukan kerjasama antara penyidik kepolisian dengan pihak rumah sakit, klinik-klinik bersalin maupun tempat-tempat praktek kebidanan, guna mendapatkan informasi dan data tentang penangganan kasus yang berkaitan dengan tindak pidana pasca aborsi criminal, serta upaya untuk mencegah terjadinya tindakan aborsi yang dilakukan oleh oknum rumah sakit maupun klinik-klinik bersalin dan tempattempat praktek kebidanan.

\section{B. Pengaturan tentang Aborsi di Indonesia}

Definisi aborsi menurut Kitab Undangundang Hukum Pidana (KUHP) adalah pengeluaran hasil konsepsi pada setiap stadium perkembangannya sebelum masa kehamilan yang lengkap tercapai (38-40 minggu) atau pengeluaran hasil konsepsi sebelum janin dapat hidup di luar kandungan (berat kurang dari 500 gram atau kurang dari 20 minggu), aborsi sebenarnya telah diatur dalam UndangUndang tentang Kesehatan Tahun 2009 dan Peraturan Pemerintah Nomor 61 Tahun 2014 tentang Kesehatan Reproduksi. Bahkan, pemerintah telah mengeluarkan Peraturan Menteri Kesehatan (Permenkes) Nomor 3 Tahun 2016 tentang Pelatihan dan Penyelenggaraan Pelayanan Aborsi atas Indikasi Kedaruratan Medis dan Kehamilan Akibat Perkosaan.

\section{Resiko Tindakan aborsi}

Aborsi memiliki risiko penderitaan yang berkepanjangan terhadap kesehatan maupun keselamatan hidup seorang wanita. Tidak benar jika dikatakan bahwa seseorang yang melakukan aborsi ia "tidak merasakan apaapa dan langsung boleh pulang". Resiko kesehatan terhadap wanita yang melakukan aborsi berisiko kesehatan dan keselamatan secara fisik dan gangguan psikologis. Risiko kesehatan dan keselamatan fisik yang akan dihadapi seorang wanita pada saat melakukan aborsi dan setelah melakukan aborsi adalah:

1. Kematian mendadak karena pendarahan hebat.

2. Kematian mendadak karena pembiusan yang gagal.

3. Kematian secara lambat akibat infeksi serius disekitar kandungan.

4. Kerusakan leher rahim (Cervical Lacerations) yang akan menyebabkan cacat pada anak berikutnya.

D. Pengaturan Tindak Pidana Aborsi Menurut Kitab Undang-Undang Hukum Pidana (KUHP)

Masalah aborsi (pengguguran kandungan) yang dikualifikasikansebagai tindak pidana yang dapat kita lihat dalam KUHP walaupun dalam Undang-Undang Nomor 36 tahun 2009 Tentang Kesehatan memuat sanksi terhadap 
perbuatan aborsi tersebut. KUHP mengatur berbagai kejahatan maupun pelanggaran. Kejahatanyang diatur di dalam KUHP adalah masalah Abortus Criminalis.

E. Pengaturan Tindak Pidana Aborsi Menurut Undang-Undang Kesehatan

Undang-Undang Kesehatan Nomor 36 Tahun 2009 ditulis secara jelas bahwa aborsi merupakan perbuatan yang dilarang kecuali dalam indikasi medis. Penjelasan Pasal 75 ayat (2) huruf a dan b disebutkan "tindakan medis dalam bentuk pengguguran kandungan dengan alasan apapun dilarang karena bertentangan dengan norma hukum, norma agama, norma kesusilaan dan norma kesopanan." Namun, hal ini dapat dikecualikan apabila ada indikasi kedaruratan medis yang dideteksi sejak usia dini kehamilan, baik yang mengancam nyawa si ibu dan/atau janin, yang menderita penyakit genetik beratdan/atau cacat bawaan, maupun yang tidak dapat diperbaiki sehingga menyulitkan bayi tersebut hidup di luar kandungan atau kehamilan akibat perkosaan yang dapat menyebabkan trauma psikologis bagikorban perkosaan.

Pasal 76 butir b bahwa yang berwenag melakukan aborsi adalah tenaga kesehatan yang memiliki keterampilan dan kewenagan yang memiliki sertifikat yang ditetapkan oleh Menteri. Undang-Undang Kesehatan tidak semua dokter boleh melakukan aborsi. Syarat lainnya disebutkan dalam butir e, yakni penyedia layanan kesehatan yang memenuhi syarat yang ditetapkan oleh Menteri. Bagaimana jika aborsi dilakukan tanpa memenuhi syarat-syarat yang ditetapkan pada Pasal 75 dan 76 undang-undang kesehatan tersebut. Ketentuan itu talah diatur dalam Pasal 194 Undang-Undang Kesehatan yakni, Setiap orang yang dengan sengaja melakukan aborsi tidak sesuai dengan ketentuan sebagaimana dimaksudkan dalam Pasal 75 ayat (2), dipidana dengan pidana penjara paling lama sepuluh tahun dan denda paling banyak Rp.1.000.000.000.000.- (satu miliar).

\section{METODE PENELITIAN}

Peneliti menggunakan pendekatan kualitatif dengan metode deskriptif yaitu dengan cara mengumpulkan, menganalisis, membuat gambaran dan mempersingkat segala kondisi dan situasi dari data yang telah terkumpul. Denzin \& Lincoln (1944) dalam Anggito \& Setiawan (2018, hlm 7) menyebut jika penelitian kualitatif merupakan penelitian dengan penggunaan latar naturalis yang bermaksud untuk menggambarkan peristiwa yang ada. Penelitian deskriptif kualitatif menyajikan out put data sesuai dengan kenyataan yang didapat tanpa adanya unsur kebohongan atau manipulatif, semuanya didasarkan pada kenyataan di lapangan. Tujuan dari penelitian kualitatif yaitu untuk memberikan gambaran, menjelaskan dan merespon secara rinci topik yang dibahas dan diteliti dengan cara mempelajari semaksimal mungkin suatu kejadian, dalam hal ini, peneliti berperan penting karena menjadi kunci keberhasilan dalam menentukan hasil penelitian yang telah dibuat.

\section{HASIL DAN PEMBAHASAN}

A. Faktor Terjadinya Tindakan Aborsi

Dengan demikian dari hasil penelitian menunjukkan bahwa faktor yang melatarbelakangi remaja melakukan aborsi secara garis besar dibedakan beberapa faktor, yaitu faktor ekonomi, faktor sosial, factor masih kuliah atau sekolah, Kurangnya edukasi mengenai seks dan kurangnya tanggungjawab pada remaja meningkatkan kecenderungan pada remaja untuk melakukan tindakan aborsi, diberbagai daerah, setiap tahunnya banyak perempuan khususnya remaja mengalami kehamilan yang tidak diinginkan. Sebagian besar dari remaja tersebut memilih untuk mengakhiri kehamilan mereka meski tahu hal itu melanggar hukum dan dilarang agama. Aborsi menarik untuk dibahas karena meskipun dilarang oleh hukum tetapi jumlahnya cenderung meningkat dari tahun ke tahun. Oleh karena itu, untuk menjembatani kesenjangan antara norma hukum yang berkaitan dengan aborsi yang berisi laranganlarangan dan sanksi pidana dengan fenomena aborsi yang semakin meningkat di dalam masyarakat, pengaturan hukum tentang aborsi seharusnya bersikap lebih adil terhadap perempuan dengan memberikan berbagai solusi. Solusi itu berupa sarana pendukung yang menjamin rasa aman bagi perempuan yang menderita karena kehamilan yang tidak diinginkan, sehingga mereka tidak menempuh jalan pintas dengan melakukan aborsi.

\section{B. Cara dan tindakan Aborsi}

Ada dua cara yang dilakukan dalam tindakan aborsi, yaitu:

1. Aborsi bisah dilakukan dengan sendiri 
tanpa ada pertolongan siapapun. Aborsi telah dilakukan dengan sendiri seperti dengan cara menkonsumsi obat-obatan yang membahayakan janin bayi dengan cara melakukan perbuatan-perbuatan secara sengaja dan ingin menggugurkan janin dalam kandungannya.

2. Aborsi dilakukan orang lain. Kasus aborsi ini bisah dibantukan oleh orang lain yakni bisah saja seorang dokter, bidan atau dukun beranak. Ada berbagai cara-cara yang digunakan juga berfariasi dilakukan.

Kalau aborsi yang dilakukan pada seorang dokter atau bidan biasannya ada 5 tahapan, yakni,

1. Bayi yang dibunuh dengan berbagai cara seperti, ditusuk atau diremukkan di dalam kandungan.

2. Bayi selalu dipotong-potong tubuhnya sihingga bisah dapat dan mudah dikeluarkan.

3. Kemudian bayi yang dikeluarkan sering menggunakan tang.

4. Kemudian potongan-potongan diatur kembali dan bisa memastikan bayi dapat keluar semua.

5. Bayi yang sudah dipotong-potong tersebut kemudian dibuang ke tempat seperti disungai, dikubur di tanah kosong, atau buang ditempat-tempat yang tidak ada penghuninya.

Sedangkan seorang dukun beranak yaitu bisa saja sering melakukan tindakan aborsi selalu dengan memberi ramuan obat-obatan kepada calon ibu dan menurut perut calon ibu untuk mengeluarkan secara paksa janin dalam kandungannya. Hal seperti ini memang sangat berbahaya karena pengurutan belum tentu bisah dipastikan membuahkan hasil yang baik dan diinginkan bahkan bisa saja membawa cara bagi janin dan trauma hebat bagi calon ibu itu yang harus dipikirkan oleh Wanita.

\section{Faktor-Faktor yang Melatar belakangi}

Terjadinya Aborsi Pada Remaja

Pada kasus remaja yang melakukan aborsi, faktor perubahan gaya hidup akibat kemajuan teknologi informasi serta pergaulan yang tidak dibarengi oleh pengetahuan dan pemahaman mengenai kesehatan reproduksi menjadi faktor yang melatarbelakangi terjadinya kehamilan yang tak diinginkan. Faktanya, pengetahuan tentang reproduksi yang diperoleh dari sekolah atau kampus kurang mendukung, ditambah lagi adanya mitos-mitos yang diperolehnya dari teman sebaya, media massa seperti majalah, blue film, dan dari internet.

Adanya hal tabu untuk membahas persoalan seks dan reproduksi juga bisa berakibat dalam kasus ini. Dari hal-hal tersebut tentu saja berakibat mengenai proses reproduksi seperti pernikahan yang tidak direncanakan, adanya pergaulan bebas (seks pra nikah), dan kekerasan seksual pada saat pacaran. Teknologi yang berkembang pesat saat ini membuat para remaja dapat mengakses berbagai informasi mulai dari yang positif sampai yang negatif, dari yang bermanfaat secara ilmiah sampai dengan hiburan termasuk akses pornografi. Remaja zaman sekarang memiliki gadget untuk mengakses berbagai informasi termasuk pornografi. Tayangan pornografi dapat merangsang dan menyebabkan orang terbiasa untuk berperilaku dan meniru apa yang telah dilihatnya. Hal tersebut menyebabkan para remaja ini mulai ingin tahu tentang kehidupan seksual manusia.

Tabel 1. Kasus Aborsi Kota Ternate

\begin{tabular}{ccc}
\hline Tahun & Kasus & Jumlah \\
\hline 2020 & 8 Kasus Aborsi & \\
\hline 2021 & 11 Kasus Aborsi & 19 Kasus \\
\hline
\end{tabular}

Dari tabel diatas kita menganalisis bahwa bisah saja kasus aborsi dikota ternate setiap tahun meningkat peneliti mencoba mengambil kasus ditahun 2020 terdapat delapan (8) kasus aborsi,dengan masingmasing profesi 5 dari statusnya sebagai mahasiswa dan tiga nya (3) dari kalangan pekerja swasta. Kemudian ditahun 2021 meningkat menjadi 11 kasus, diantaranya 6 orang dari kalangan mahasiswa, 2 dikalangan pelajar tingakat sekolah menengah umum, dan 3 orang dari pekerja swwasta. Untuk itu kasus yang terkafer oleh penegak hukum saja bisa terjadi seperti ini, apalagi tidak terkafer oleh penegak hukum, bisah saja melebihi apa yang perkirakan oleh rasional manusia.

Hal seperti ini bisah terjadi, setiap tahun bisah saja menurun bahkan bisah saja meningkat tinggal bagimana regulasi yang seharusnya sudah diperhatikan oleh pemerintah kecamatan, kelurahan, bahkan pemerintah kota tenate untuk bisah menimalesir angka kejahatan abori dikota ternate. Aborsi merupakan masalah yang sarat dengan nilainilai sosial, budaya, agama, 
dan politik. Aturan normatif legal-formal menolak aborsi meski masih ada ruang untuk hal-hal khusus. Aturan normatif sosialbudaya, agama yang informal pada umumnya juga menolak aborsi, meski terdapat variasi dan kelonggaran di sana sini.

Remaja, bahwa pada masa pubertas inilah masa di mana mereka mencari jati diri dan arti dari hidup. Pada masa-masa ini pula remaja memiliki rasa ingin tahu yang begitu besar dalam segala hal. Tak heran apabila beberapa diantara mereka seringkali mengambil keputusan yang berisiko hanya untuk merasakan hal-hal yang belum mereka ketahui, termasuk misteri seksualitas. Banyak diantara mereka yang merasakan tidak sabar akan hal tersebut.

Aborsi biasa terjadi dikalangan remaja saat ini adalah, ketidakmauan menjadi seorang ibu yang masih beumur sangat mudah, Hal ini biasanya disebabkan karena kurangnya informasi yang didapatkan oleh remaja. Banyak remaja yang masih menganggap bahwa melakukan hubungan seksual pertama kali tidak dapat menyebabkan kehamilan. Akhirnya ketika kehamilan yang tidak diinginkan terjadi, ia tidak siap untuk menjadi ibu. Kemudian alas an masih sekolah atau kuliah, tapi kalua menurut studi kami remaja itu tidak sampai 20 persen. Ada yang alasannya karena masih sekolah, tapi tidak terlalu banyak dibandingkan dengan wanita menikah yang karena kegagalan konstrasepsi.

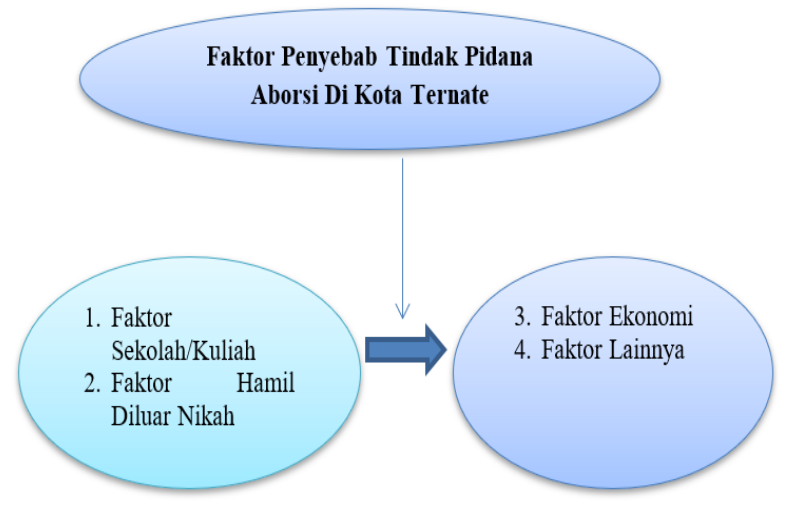

Gambar 1. Faktor Penyebab Tindak Pidana Aborsi di Kota Ternate

D. Tindakan Hukum Kasus Aborsi Menurut Hukum Pidana

KUHP melarang aborsi dan sanksi hukumnya cukup berat. Hukumnya tidak hanya ditujukan kepada wanita yang bersangkutan tetapi kepada semua pihak yang terlibat dalam kejahatan itu. Ada sanksi tegas bagi pelaku baik yang melakukan aborsi maupun yang membantu melakukan aborsi. Dewasa ini tindakan aborsi semakin meningkat walaupun ada sanksi tegas yang menanti bagi yang membuat, apalagi banyak tindakan aborsi yang dilakukan oleh mereka yang belum menikah yang biasanya di dominasi oleh anak yang tergolong masih di bawah umur semakin membuat masalah perihal aborsi penting untuk di perhatikan KUHP memandang aborsi sebagai tindak kejahatan terhadap nyawa dan menjatuhkan hukuman pidana kepada siapa saja yang terlibat, baik wanita yang meminta pelayanan, maupun orang yang menganjurkan, serta tenaga yang memberikan pelayanan aborsi.

Saat ini aborsi masih merupakan masalah kontroversial di masyarakat Indonesia, namun terlepas dari kontroversi tersebut, aborsi diindikasikan merupakan masalah kesehatan masyarakat karena memberikan dampak pada kesakitan dan kematian ibu. Terlepas dari kebijakan hukum negara tersebut, aborsi merupakan fenomena yang terkait erat dengan nilai-nilai sosial budaya agama yang hidup dalam masyarakat. dalam konteks Indonesia aborsi lebih condong sebagai aib sosial daripada manifestasi kehendak bebas tiap individu.

\section{E. Dampak Negatif Pergaulan Bebas}

Budaya pergaulan bebas dan Seks bebas lebih banyak menimbulkan dampak negatif bagi kehidupan dan martabat kaum remaja atau dewasa yang melakukannya. Dampak negatif tersebut adalah:

1. Hilangnya harga diri

Hilangnya kehormatan dan jatuh martabatnya baik di hadapan Tuhan maupun sesama manusia serta merusak masa depannya, dan meninggalkan memori buruk yang berkepanjangan bukan saja kepada pelakunya bahkan kepada seluruh keluarganya. Kehormatan sangat penting bagi setiap manusia, terutama pada wanita. Jika kehormatan tersebut sudah hilang maka akan jelas terlihat perbedaannya dengan wanita yang masih menjaganya. Prestasi menurun Apabila seorang remaja sudah melakukan seks bebas, maka pikirannya akan selalu tertuju pada hal negatif tersebut. Rasa ingin mengulanginya selalu ada, sehingga tingkat kefokusannya dalam mengikuti proses belajar akan menurun. 
Malas belajar, malas mengerjakan tugas dan lain sebagainya dapat menurunkan prestasi remaja tersebut.

2. Hamil di Luar Nikah

Hamil diluar nikah akan sangat menimbulkan masalah bagi pelaku. Terutama bagi remaja yang masih sekolah, pihak sekolah akan mengeluarkan pelaku jika ketahuan siswanya kedepatan ada yang hamil. Sedangkan bagi pelaku yang kuliah hamil diluar nikah akan menimbulkan rasa malu yang luar biasa terutama orang tua.

3. Aborsi dan Bunuh Diri

Terjadinya hamil diluar nikah akibat seks bebas akan menutup jalan pikiran pelaku, guna menutupi keburukan ataupun mencari jalan keluar agar tidak merusak nama baik dirinya dan keluarganya hal tersebut dapat berujung pada pembunuhan janin melalui aborsi bahkan bunuh diri.

4. Tercorengnya Nama Baik Keluarga

Semua orang tua akan merasa sakit hatinya jika anak yang dibangga-banggakan juga diidam-idamkan hamil diluar nikah. Nama baik keluarga akan tercoreng karna hal tersebut, dan hal tersebut akan meninggalkan luka yang mendalam dihati keluarga. Tekanan batin yang mendalam dikarenakan penyesalan. Akibat penyesalan tersebut pelaku akan sering murung dan berpikir yang tidak rasional. Terjangkit Penyakit, mudah terjangkit penyakit HIV/ AIDS serta penyakit-penyakit kelamin yang mematikan, seperti penyakit herpes dan kanker mulut rahim. Jika hal tersebut terus dilakukan, penyakit tersebut dapat menularkannya pada orang lain disekitarnya dan cukup membahayakan.

\section{F. Refleksi Moral Menangkal Budaya Seks Bebas}

Persoalan pergaulan dan seks bebas harus ditangani oleh orang tua, sekolah, Pemerintah, dan remaja sendiri. Diperlukan refleksi moral untuk menangkalnya. Salah satunya moral yang dapat dilakukan untuk menangkal budaya seks bebas:

1. Hindari lingkungan yang buruk

Lingkungan merupakan area bersosialisasi setelah keluarga.Ketika lingkungan yang digunakan untuk bersosialisasi bukanlah lingkungan yang baik, maka perilaku menyimpang dapat saja terjadi. Menjadi pekerjaan orang tualah untuk mendidik anaknya supaya dapat mengerti baik dan buruk suatu perilaku sejak dini.
Namun terkadang karena kesibukan dari orang tua maka anak yang tidak mendapat pengawasan dengan baik dan akhirnya banyak dari mereka yang terjerumus pada pergaulan bebas, banyak dari orang tua yang berdalih jika pekerjaan mereka adalah untuk kebutuhan anak juga. Hal ini memang dibenarkan namun ketika anak merasa diabaikan maka sebagai pelampiasannya, anak akan dengan mudah bergaul dengan pergaulan yang salah. Solusi yang tepat untuk hal ini tentu dapat dilakukan dengan cara membagi waktu antara pekerjaan dan waktu untuk mengurusi serta memperhatikan anak-anak dengan baik.

2. Batasi waktu keluar rumah

Waktu untuk bersosialisasi memang penting namun harus ada aturan dan batas-batasannya. Batasan dan aturan di dalam keluarga, harus dibicarakan dengan seluruh anggota keluarga agar nyaman satu dengan yang lain. Aturan yang dibuat tersebut dapat digunakan untuk membatasi ruang lingkup anak supaya tidak terjerumus pada pergaulan yang tidak sehat, terutama pada malam hari, sebaiknya anak tidak boleh keluar kecuali ada hal yang mendesak atau dapat pula dengan didampingi oleh orang tua. Tidak adanya batasan waktu, membuat seorang anak akan lebih bebas sehingga dampak dari pergaulan bebas pun tidak dapat dielakkan.

Mengisi waktu kosong Ada banyak kegiatan yang dapat dilakukan untuk mengisi waktu yang kosong dengan kegiatan yang bersifat positif. Mengisi waktu kosong menghindarkan diri dari sikap bermalas-malasan atau bahkan pergi keluar untuk bergaul dengan mereka yang telah terjerumus. Untuk remaja, isilah waktu kosong dengan kegiatan - kegiatan yang mendukung keahlian ataupun kemampuan seperti ekstrakurikuler dan organisasi, dengan begitu, waktu akan terisi oleh hal - hal yang bernilai.

3. Jangan salah bergaul

Bagi remaja yang kini sedang pubertas, mereka pasti akan memilih teman yang mengasyikan daripada yang baik. Walaupun tidak boleh membeda - bedakan teman, tapi ada baiknya apabila memilih teman yang memang baik untuk masa depan kita. Memilih teman yang dalam 
artian tidak menjerumuskan kita pada kondisi yang buruk. Apabila seorang remaja sudah memiliki teman yang "tidak benar" maka secara tidak sadar remaja tersebutakan terbawa arus yang "tidak benar".

4. Memperdalam iman

Kuatnya iman dan dekatnya hubungan remaja dengan Tuhan-nya akan membawa mereka jauh dari kata dosa. Semakin banyak kita memperdalam dan memperkuat iman, maka semua ajaran yang menyimpang pun sudah pasti tidak akan dilakukan. Kuatnya iman inilah yang membawa mereka jauh dari terjerumus kata dosa. Tidak mencoba-coba Masa remaja yang dipenuhi dengan teka-teki sehingga mengakibatkan rasa ingin tahu yang besar membuat remaja ingin mencoba hal - hal baru. Memang wajar sekali remaja memiliki perasaan tersebut, tapi ada baiknya dipilah terlebih dahulu apa yang harus di coba dan tidak. Hal - hal yang harus mereka coba adalah sesuatu yang bersifat positif dan membawa mereka pada keberhasilan. Mencoba sesuatu yang bersifat negatif akan membawa mereka pada hal yang tidak diinginkan di kemudian hari.

5. Peranan Orang Tua

Orang tua dan keluarga adalah lingkungan yang terdekat dengan remaja. Pengawasan orang tua dalam perkembangan remaja haruslah intensif. Orangtua harus meluangkan waktunya bersama anak-anak mereka agar anak-anak tersebut merasa diperhatikan. Rasa diperhatikan inilah yang membuat remaja akan selalu nyaman berada dirumah. Walaupun begitu, orang tua juga harus bisa menjadi teman bagi anak - anak mereka agar nantinya mereka akan selalu merasa lengkap berada di lingkungan keluarga.

\section{SIMPULAN DAN SARAN}

\section{A. Simpulan}

Aborsi menarik untuk dibahas karena meskipun dilarang oleh hukum tetapi jumlahnya cenderung meningkat dari tahun ke tahun. Oleh karena itu, untuk menjembatani kesenjangan antara norma hukum yang berkaitan dengan aborsi yang berisi laranganlarangan dan sanksi pidana dengan fenomena aborsi yang semakin meningkat di dalam masyarakat, pengaturan hukum tentang aborsi seharusnya bersikap lebih adil terhadap perempuan dengan memberikan berbagai solusi, Aborsi secara aspek hukum dapat terjadi dikota ternate karena masih kekosongan Peraturan Daerah (Perda) Pemerintah kota ternate seharusnya sudah membuat salah satu prodak Perda untuk pengelola rumah kos-kosan, ataukah membangun sebuat kontrol sosial yang kuat dimasing-masing kelurahan, sehingga bisah membantu pemerintah kelurahan, melaksanakan patroli ditempat-tempat hunian rumah kosan maupun kontrakan para mahasiswa maupun masyarakat yang diduga melakukan kumpul kebo. Solusi itu berupa sarana pendukung yang menjamin rasa aman bagi perempuan yang menderita karena kehamilan yang tidak diinginkan, sehingga mereka tidak menempuh jalan pintas dengan melakukan aborsi.

\section{B. Saran}

Untuk itu, upaya pemerintah kota ternate seharusnya mencari solusi untuk menimalesir angka tindakan aborsi tiap tahun dikota dengan cara membuat salah satu prodak perda mengatur tentang hunian rumah kosan sehingga tratur antara penghuni laki-laki maupun perempuan. Seluruh pemangku kepentingan terkait juga perlu terus melakukan sosialisasi dan meningkatkan sosialisasi kesehatan reproduksi sedini mungkin, yaitu sejak remaja. Sosialisasi mengenai kesehatan reproduksi harus ditekankan pada layanan kesehatan reproduksi, melalui layanan kesehatan reproduksi remaja, kesehatan masa pra-kehamilan, selama kehamilan, persalinan, pasca-melahirkan.

\section{DAFTAR RUJUKAN}

Aborsi Janin Mulai Makan Nanas Hingga Telan Obat, Kini Mereka Dipenjara. Diakses 15 November 2021. https://bit.ly/2WhuPo3

Amirudin dan Zainal Asikin, 2016, Pengantar Metode Penelitian Hukum, Cet. IX, Rajawali Pers, Jakarta

Arief, Barda Nawawi, 2016, Bunga Rampai Kebijakan Hukum Pidana:

Pemerkosaan. Lex Crimen, 5(1), h. 546 Soge, Paulinus. Op.Cit., h. 1487 Wahyu 
Amirudin dan Zainal Asikin, 2016, Pengantar Metode Penelitian Hukum, Cet. IX, Rajawali Pers, Jakarta

Arief, Barda Nawawi, 2016, Bunga Rampai Kebijakan Hukum Pidana:

Batalipu, Bunga Mutiara. (2016). Kajian Yuridis Atas Legislasi Aborsi Dalam Kasus

Ekotama, Suryono, 2011, Abortus Provokatus Bagi Korban Perkosaan Perspektif Viktimologi, Kriminologi dan Hukum Pidana, Universitas Atmajaya, Yogyakarta
Gosita, Arif, 1985, Masalah Korban Kejahatan (Kumpulan Karangan), Akademika Presindo, Jakarta.

Kusmayanto, SCJ, 2009, Kontroversi Aborsi, PT. Gramedia Widiasarana Indonesia, Jakarta.

Jerry Suarjana Putra, Agus; Ari Atu Dewi, A, 2016. Aborsi Oleh Korban Pemerkosaan Ditinjau Berdasarkan Kitab Undang-undang Hukum Pidana Undang-undang No. 36 tahun 2009 tentang Kesehatan. Kertha Wicara, URL 